\title{
DIAGNOSIS CEPAT TERHADAP PENYAKIT BAKTERIAL Aeromonas hydrophila DENGAN MENGGUNAKAN METODE SEROLOGI
}

\author{
Hambali Supriyadi*), Hariyadi Mangunwiryo" ${ }^{\star *)}$ dan Johan Effendi K.")
}

\section{ABSTRAK}

Keterlambatan serta kurang tepatnya diagnosis suatu penyakit ikan merupakan salah satu faktor penyebab lambatnya dan salahnya tindakan pengobatannya. Tujuan dari penelitian ini adalah untuk mendapatkan cara diagnosis yang tepat dan cepat terhadap penyakit bakterial, khususnya yang disebabkan oleh bakteri Aeromonas hydrophila dengan menggunakan metode serologi.

Serum anti yang dipakai berasal dari kelinci New Zealand yang telah diimunisasi dengan antigen $A$. hydrophila strain no.26 (WC26 dan CFE26), dan strain 31 (WC31 dan CFE31) dari koleksi Balitkanwar. Serum anti yang dihasilkan diuji titernya terlebih dahulu. Uji diagnosis dilakukan dengan cara aglutinasi langsung dan uji presipitasi (Ouchterclony).

Hasil penelitian menunjukkan bahwa titer antibodi tertinggi diperoleh dari serum kelinci yang diimunisasi dengan $A$. hydrophila strain 26, yaitu jenis WC26. Uji diagnosis terhadap beberapa isolat yaitu isolat $A$. hydrophila no. $1 ; 8, ; 10 ; 11$; dan 12 menunjukkan bahwa isolat-isolat tersebut di atas bereaksi positif (aglutinasi) terhadap serum anti WC26. Dari hasil uji presipitasi diketahui bahwa isolat no.1 menunjukkan kesamaan epitop dengan A. hydrophila strain 26, sedangkan isolat no.11 mempunyai kesamaan epitop dengan isolat no.31.

ABSTRACT: Quick diagnostic of bacterial desease Aeromonas hydrophila by serological method. By: Hambali Supriyadi, Hariyadi Mangunwiryo and Johan Effendi $K$.

The failure of control of bacterial disease was sometime caused by the use of inaccurate diagnostic method. The objective of this research is to find out the rapid and suitable diagnostic method which can be used especially to diagnose bacterial disease.

Antisera used was collected from New Zealand rabbit immunized with A. hydrophila antigen strain no.26 and strain 31. Antibody titer of antisera was measured. Diagnostic was done by direct agglutination and precipitation test.

The results indicated that the higher antibody titer resulted from sera collected from rabbit immunized by a whole cell antigen of A. hydrophila strain No.26. Test of bacterial isolates no. 1 , 8; 10; 11; and 12 indicated that all of the isolates were positively reacted (agglutinated) with antisera WC26. Result from precipitation test indicated that isolate no. 1 possessed analog epitope with A. hydrophila strain no.1, meanwhile isolate no. 11 possessed analog epitope with isolate no. 31.

KEYWORDS: Fish diseases, serology, Aeromonas hydrophila, ouchterclony, agglutination.

\section{PENDAHULUAN}

Penyakit ikan merupakan salah satu masalah besar yang harus dihadapi dalam usaha budidaya ikan maupun udang. Penyakit bakterial merupakan salah satu penyakit yang sering menimbulkan kerugian yang tidak sedikit.
Masalah yang ada adalah sering terjadinya keterlambatan dan kesalahan penggunaan obat. $\mathrm{Hal}$ tersebut diakibatkan karena penggunaan metode diagnosis yang kurang cepat dan tepat. Dengan pemakaian metode yang cepat dan tepat terhadap suatu penyakit maka cara penanggulangan terhadap penyakit tersebut dapat di-

*) Peneliti pada Balai Penelitian Perikanan Air Tawar, Sukamandi

**) Peneliti pada Pusat Penelitian dan Pengembangan Perikanan, Jakarta 
laksanakan dengan cepat, dan tepat pula dalam pemilihan obat.

Salah satu cara yang sering digunakan adalah metode diagnosis serologis. Cara yang sederhana tapi masih dapat diandalkan dalam metode serologis ini antara lain dengan penggunaan antibodi poliklonal.

Metode serologi ini dapat dipakai untuk membedakan strain-strain bakteri penyebab penyakit pada ikan. Misalnya Harrel et al. (1976) dan Johnsen (1977) telah membedakan Vibrio anguillarum yang diisolasi dari Salmonids dengan Vibrio yang diisolasi dari ikan laut lainnya. Selain itu metode serologi telah digunakan dalam perbandingan patogenitas dari Edwardsiella tarda (Salati dan Kusuda, 1985).

Teknik diagnosis lain yang sifatnya lebih spesifik adalah dengan menggunakan antibodi monoklonal. Dengan metode ini jasad penyebab penyakit akan dapat didiagnosis lebih cepat dan tepat (Campbell, 1986).

\section{BAHAN DAN METODE}

\section{Antigen dan Pembuatan Sediaannya}

Bakteri yang dipakai pada pembuatan antigen adalah $A$. hydrophila strain no.26 dan strain no.31 (strain G) koleksi Balitkanwar. Antigen dibuat dengan dua sediaan, yaitu:

a) Ekstrak bebas sel (cell free extract): dibuat dengan cara pemanasan dalam penangas air pada suhu $80^{\circ} \mathrm{C}$ selama $1 \mathrm{jam}$, kemudian dipusingkan pada putaran $4000 \mathrm{rpm}$ selama 15 menit. Setelah itu supernatannya diambil sebagai cell free extract (CFE).

b) Sel utuh (whole cell): dibuat dengan pemberian alkohol $95 \%$ pada bakteri yang dipanen selama 30 menit, setelah itu dicuci dengan salin dengan jalan dipusingkan, sehingga didapat sediaan yang berupa sel utuh (WC). Konsentrasi antigen dibuat sedemikian rupa hingga mencapai jumlah sekitar $10^{8} \mathrm{sel} / \mathrm{ml}$.

Dengan demikian diperoleh sediaan antigen keseluruhan, yaitu whole cell 26 (WC26), whole cell 31 (WC31), cells free extract 26 (CFE26) dan cell free extract 31 (CFE31).

\section{Imunisasi Kelinci}

Kelinci yang dipakai adalah jenis New Zealand dengan bobot badan berkisar antara 1,25-1,50 kg/ekor.

Masing-masing jenis antigen yang telah disiapkan diberikan dalam 3 tahapan, yaitu dosis I $0,1 \mathrm{~mL} /$ ekor diberikan pada penyuntikan pertama. Dosis II sebesar $0,2 \mathrm{~mL} /$ ekor diberikan pada penyuntikan ke-2, yaitu 1 minggu setelah penyuntikan pertama. Dosis III sebesar $0,5 \mathrm{~mL} /$ ekor diberikan pada penyuntikan ke-3, yaitu 1 minggu setelah penyuntikan ke-2.

Penyuntikan dilakukan melalui pembuluh darah (intra venous) yang ada pada daun telinga kelinci. Setelah penyuntikan akhir kelinci kemudian diinkubasikan selama dua minggu.

\section{Pengambilan Serum}

Darah diambil dari kelinci yang telah diimunisasi dengan menggunakan alat suntik volume $5 \mathrm{~mL}$ dari pembuluh darah pada ujung daun telinga. Darah yang diperoleh ditampung dalam tabung venoject dan dibiarkan sampai serum dengan butir darah merahnya terpisah.

Serum yang diperoleh kemudian dipusingkan dengan kecepatan putaran 3000 rpm selama 15 menit supaya serum bebas dari butir darah merah. Kemudian serum tersebut diawetkan dengan menggunakan mertiolat dan disimpan dalam suhu $-20^{\circ} \mathrm{C}$.

\section{Uji Titer Antibodi Serum Anti}

Uji titer antibodi dilakukan dengan menggunakan cawan mikro (microplate). Masingmasing serum (WC26, WC31, CFE26 dan CFE31) diencerkan dengan pengenceran ganda, yaitu 0; $2 ; 4 ; 8 ; 16 ; 32$; sampai 256 kali. Volume masingmasing sebesar 50 mikro liter $(\mu \mathrm{L})$. Ke dalam lubang-lubang pada cawan mikro tersebut kemudian dititarkan antigen sebanyak $50 \mu \mathrm{L}$. $A$. hydrophila strain 26 dipakai untuk menitar serum anti WC26 dan CFE26 sedangkan strain 31 dipakai untuk menitar serum anti WC31 dan CFE31. Pengamatan dilakukan terhadap aglutinasi yang terjadi pada masing-masing lubang. Uji titer antibodi dari masing-masing serum anti dilakukan dalam 3 cawan mikro (sebagai ulangan). 


\section{Uji Aglutinasi Langsung}

Uji aglutinasi langsung dilakukan dengan menggunakan gelas obyek. Di atas gelas obyek diteteskan serum anti masing-masing sebanyak $5 \mu \mathrm{L}$, dicampur dengan sediaan antigen sebanyak $5 \mu \mathrm{L}$ dan kemudian diaduk dengan menggunakan jarum ose. Uji aglutinasi langsung dilakukan terhadap serum anti WC26, CFE26, WC31 dan CFE31 terhadap antigen spesifik masing-masing. Pengamatan dilakukan terhadap aglutinasi yang terjadi.

\section{Uji Diagnosis beberapa Isolat Bakteri}

Uji coba diagnosis/karakterisasi beberapa isolat bakteri dilakukan dengan menggunakan serum anti WC 26 dan WC31. Isolat bakteri yang digunakan adalah isolat yang dikoleksi dari beberapa ikan sakit, dengan kode nomor isolat 1 ; $8 ; 10 ; 11$ dan 12. Semua isolat dari hasil uji awal menunjukkan karakter tumbuh dalam Rimler Shotts (RS) Agar, di mana koloni yang berwarna kuning dan sitokrom oksidase positif menunjukkan bahwa bakteri tersebut adalah $A$. hydrophila.

Uji ini dilakukan dengan uji aglutinasi yang menggunakan cawan mikro (microplate) dengan metode seperti yang dilakukan untuk uji titer sesuai dengan metode Robertson (1990), dengan tujuan untuk sekaligus mengetahui kedekatan/ kesamaan karakter dari masing-masing isolat.

Antisera WC26 dan WC31 (masing-masing dilakukan dengan 5 seri sesuai dengan jumlah isolat yang akan diuji) diencerkan dengan pengenceran ganda sampai dengan pengenceran 512 kali. Kemudian masing-masing dititar dengan menggunakan bakteri uji, yaitu isolat $1 ; 8 ; 10 ; 11$ dan 12 dalam sediaan cair, dengan kandungan bakteri $10^{7} \mathrm{sel} / \mathrm{mL}$. Pengamatan dilakukan terhadap aglutinasi yang terjadi pada berbagai tingkat pengenceran.

\section{Uji Presipitasi}

Media yang dipakai terbuat dari $1 \mathrm{~g}$ agar (DIFCO) ditambah 0,01 $\mathrm{g} \mathrm{NaN}_{3}$ dalam $100 \mathrm{~mL}$ fosfat buffer saline (PBS) pada $\mathrm{pH} \mathrm{7,4} \mathrm{dicampur}$ dan dipanaskan sambil diaduk sampai mendidih. Media tersebut didinginkan sampai $70^{\circ} \mathrm{C}$ kemudian dituangkan ke dalam cawan petri kira-kira $15 \mathrm{~mL} /$ cawan petri, dan dibiarkan sampai membeku (Ingram, 1990).
Media agar tersebut kemudian dilubangi dengan menggunakan alat pelubang (telescopic punch) dengan jarak antar lubang $4 \mathrm{~mm}$. Jumlah lubang keseluruhan adalah 7 , yaitu 1 lubang di tengah dan 6 lubang di sekelilingnya.

Antisera yang diuji adalah anti WC26 dan anti WC31, dengan ulangan masing-masing 3 kali sehingga jumlah cawan yang dipakai adalah 6 buah.

Pada cawan 1 sampai 3 ke dalam lubang tengahnya dimasukkan $25 \mu \mathrm{L}$ antiserum WC26, kemudian kepada 6 lubang di pinggir berturutturut dimasukkan masing-masing $25 \mu \mathrm{L}$ antigen A. hydrophila strain 26 , antigen no. $1 ; 8 ; 10 ; 11$ dan 12 . Sedangkan untuk cawan 4 sampai 6 , ke dalam lubang tengahnya dimasukkan serum anti WC31 sebanyak $25 \mu \mathrm{L}$, dan pada 6 lubang di pinggir dimasukkan masing-masing antigen $A$. hydrophila strain 26 dan isolat 1; 8; 10; 11 dan 12.

Pengamatan dilakukan terhadap garis-garis presipitasi yang terbentuk di antara serum dan antigen yang berbeda. Masing-masing uji dilakukan dengan 3 ulangan.

\section{HASIL DAN PEMBAHASAN}

Setelah penyuntikan ke-1 dan ke-2 keadaan kelinci tidak menunjukkan perubahan fisik maupun perilaku. Hal ini menunjukkan bahwa tidak ada efek racun dari antigen yang diberikan. Namun setelah penyuntikan ke-3, yaitu dengan menggunakan dosis $0,5 \mathrm{~mL} / \mathrm{ekor}$ ternyata ada beberapa ekor kelinci yang kurang tahan sehingga menderita sakit.

Hasil uji titer antibodi terhadap serum yang dihasilkan menunjukkan bahwa serum yang dihasilkan dari kelinci yang diimunisasi dengan bakteri $A$. hydrophila strain 26 dengan bentuk sediaan sel utuh (WC26) menghasilkan titer antibodi yang lebih tinggi dibandingkan dengan serum yang dihasilkan dari perlakuan lainnya. Hal ini menunjukkan bahwa antigen WC26 lebih imunogenik dibandingkan dengan antigen lainnya (CFE26, WC31 dan CFE31).

Tingkat imunogenik antigen CFE26 dan CFE31 ternyata sama. Hal ini ditunjukkan dengan hasil titer antibodi yang sama (aglutinasi pada tingkat pengenceran $32 \mathrm{kali}$ ). 
Antigen WC31 memiliki sifat imunogenik yang relatif tinggi. Hal tersebut dibuktikan dengan titer antibodi yang dihasilkan, yaitu terjadi aglutinasi sampai tingkat pengenceran 64 kali. Namun demikian masih rendah apabila dibandingkan dengan antigen WC26 yang menghasilkan titer antibodi yang paling tinggi, yaitu masih terlihat pada tingkat pengenceran 256 kali (Tabel 1).

Hasil reaksi aglutinasi langsung menunjukkan bahwa serum anti WC26 bereaksi positif terhadap bakteri $A$. hydrophila strain 26 (Ah26). Demikian juga serum anti CFE26 bereaksi positif (aglutinasi) terhadap Ah26. Selain itu kedua serum anti (WC26 dan CFE26) juga bereaksi silang terhadap bakteri $A$. hydrophila strain 31 (Ah31), namun reaksi dari serum anti CFE 26 dengan bakteri Ah31 berjalan sangat lemah.

Serum anti WC31 beraksi positif baik dengan antigen Ah26 maupun Ah31. Demikian juga serum anti CFE31 bereaksi positif baik dengan antigen Ah26 maupun antigen Ah31. Hasil selengkapnya dapat dilihat pada Tabel 2.

Uji diagnosis terhadap beberapa isolat, yaitu isolat $A$. hydrophila no.1; 8; 10; 11 dan 12 menunjukkan bahwa isolat-isolat tersebut di atas bereaksi positif (aglutinasi) terhadap serum anti WC26. Namun demikian dari segi kedekatan sifatnya, ternyata bahwa isolat no.1 lebih dekat dengan asal antigen yaitu $A$. hydrophila strain 26 , diikuti oleh isolat no. 8 dan 10 . Sedangkan isolat yang paling jauh kekerabatannya adalah isolat no.11 dan 12 .

Uji dengan menggunakan serum anti WC31 menunjukkan bahwa isolat-isolat tersebut di atas juga menunjukkan terjadinya aglutinasi terhadap serum anti WC31. Kalau ditinjau dari kedekatan sifat-sifatnya, ternyata isolat no.11 paling dekat sifat-sifatnya dengan asal antigen WC31, yaitu $A$. hydrophila yang diisolasi dari gurame yang sakit. Isolat no.8; 10 dan 12 sifat-sifatnya mendekati sifat bakteri $A$. hydrophila strain 31, sedangkan isolat no. 1 adalah yang paling jauh sifat-sifatnya.

Dari hasil uji presipitasi diketahui bahwa beberapa isolat menunjukkan adanya kesamaan epitop. Seperti juga telah ditunjukkan oleh uji-uji sebelumnya, ternyata dari uji presipitasi ini menunjukkan bahwa $A$. hydrophila strain 26 mempunyai kesamaan epitop dengan isolat no.1, sedangkan isolat no.11 mempunyai kesamaan epitop dengan bakteri $A$. hydrophila yang diisolasi dari ikan gurame yang sakit (isolat no.31). Hal ini melengkapi dugaan sebelumnya bahwa isolat-isolat tersebut memiliki sifat yang sama satu sama lain. Dari sifat-sifat yang demikian dimungkinkan dapat terjadi reaksi silang apabila kita melaksanakan vaksinasi. Sehingga misalnya vaksin yang telah diproduksi sekarang yang berasal dari $A$. hydrophila isolat no. 26 dapat dipakai untuk mencegah penyakit bakterial yang diakibatkan oleh bakteri $A$. hydrophila pada ikan lain walaupun bakteri $A$. hydrophila yang menginfeksi ikan tersebut tidak sama persis dengan $A$. hydrophila strain no.26.

Tabel 1. Uji titer antibodi terhadap serum yang diimunisasi dengan antigen WC26, WC31, CFE26 dan CFE31.

Tabel 1. Antibody titer test of sera: anti WC26, anti WC31, anti CFE26 and anti CFE31.

\begin{tabular}{ccc}
\hline $\begin{array}{c}\text { Jenis serum anti } \\
\text { Antisera }\end{array}$ & $\begin{array}{c}\text { Jumlah Ulangan } \\
\text { Replication }\end{array}$ & $\begin{array}{c}\text { Titer antibodi sampai } \\
\text { tingkat pengenceran } \\
\text { Antibody level }\end{array}$ \\
\hline WC26 & 3 & 256 kali (times) \\
CFE26 & 3 & 32 kali (times) \\
WC31 & 3 & 64 kali (times) \\
CFE31 & 3 & 32 kali (times) \\
\hline
\end{tabular}


Tabel 2. Hasil uji aglutinasi antara serum anti WC26, CFE26, WC31 dan CFE31 terhadap bakteri Ah26 dan Ah31.

Table 2. Results of agglutination test of antisera WC26, CFE26, WC31 and CFE31 against bacteria Ah26 and $A h 31$.

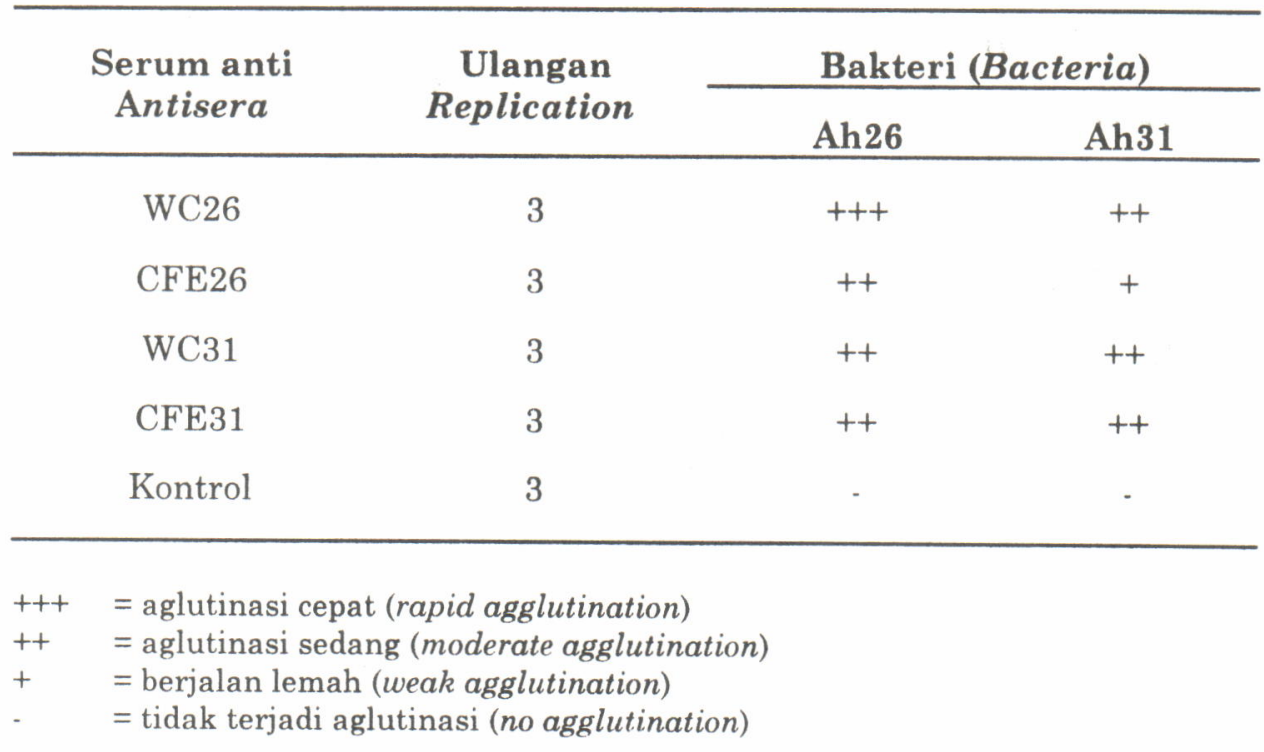

Dari hasil tersebut di atas ternyata bahwa sifat-sifat bakteri yang dekat dengan asal antigen menunjukkan reaksi spesifik baik berupa terjadinya garis-garis presipitasi maupun dengan kecepatan aglutinasinya. Dari segi kecepatan untuk mendiagnosis penyakit yang disebabkan oleh bakteri $A$. hydrophila, maka metode serologi ini dapat mendiagnosis penyakit dalam jangka waktu kurang dari 12 jam dan dapat langsung menunjukkan kesamaan strain.

Kalau dibandingkan dengan metode lain misalnya karakterisasi biokimia yang memakan waktu berkisar antara 3 sampai 6 hari, maka jelas bahwa metode serologi ini lebih cepat.

\section{KESIMPULAN}

Dari hasil yang diperoleh dapat disimpulkan bahwa metode serologi dapat digunakan untuk mendiagnosis penyakit bakterial pada ikan dengan cukup cepat. Selain itu beberapa bakteri yang berasal dari beberapa ikan sakit yaitu isolat no.1 mempunyai kesamaan sifat dengan Aeromonas hydrophila strain no.26 dan isolat no.11 mempunyai kesamaan sifat dengan isolat no.31.

\section{DAFTAR PUSTAKA}

Campbell, A.M. 1986. Monoclonal antibody technol- ogy. Laboratory Techniques in Biochemistry and Mollecular Biology. R.H. Burton and P.H. Van Knippenberg (eds). Elsivier-Amsterdam. The Netherlands.

Harrel, L.W., Novotny, A.J., Schiewe, M.H. and Hodgins, H.O. 1976. Isolation and description of two vibrios pathogenic to Pacific salmon in Puget Sound, Washington. Fish. Bull. Nat. Oceanic Atm. Adminis., 74: 447-449.

Ingram, G. A. 1990. Single radial immunodiffusion. In Techniques in fish immunology. J.S. Stolen., D.P. Anderson, B.S. Robertson, W.B. Van Muiswinkel (eds.), SOS Publications, 43 De Normandie Ave, Fair Haven, NJ07704-3303 USA.

Johnsen, G.S. 1977. Immunological studies on Vibrio anguillarum. Aquaculture 10, 221-230.

Robertson, B.S. 1990. Bacterial agglutination. In techniques in fish immunology. 1990, J.S. Stolen, T.C. Ftetcher, D.P. Anderson, B.S. Robertson, W.B. van Muiswinkel (eds.). SOS Publications, 43 DeNormandie Ave, Fair Haven, NJ07704-3303 USA.

Salati, F and R. Kusuda. 1985. Vaccine preparations used for immunization of eel Anguilla japonica against Edwardsiella tarda infection. Bull. Japan. Soc. Sci. Fish., 51:1233-1237. 